\title{
EVALUASI DAN SUPERVISI PROGRAM PEMBELAJARAN AL-QUR AN DI SEKOLAH DASAR ISLAM BILINGUAL AN-NISSA SEMARANG
}

\author{
Baqiyatush Sholihah \\ UIN Walisongo Semarang \\ baqiyatush_sholihah@walisongo.ac.id
}

\begin{abstract}
ABSTRAK
Banyak sekolah yang memberikan pendidikan al-Qur'an sebagai upaya meningkatkan mutu siswa dalam bidang keagamaan. Salah satu sekolah yang memberlakukan program pembelajaran al-Qur'an adalah Sekolah Dasar Islam Bilingual An-Nissa, yakni Baca Tulis al-Qur'an (BTQ) dan tahfidz (hafalan). Sebagaimana progam-progam pendidikan yang lain, progam tahfidz dan BTQ juga harus dievaluasi dan disupervisi. Evaluasi ini dimaksudkan untuk melihat keterlaksanaan dan ketercapaian program, efektivitas dan efisiensinya, menemukan faktor-faktor pendukung dan penghambat program, serta menemukan langkah-langkah supervisi sebagai program pembinaan yang komprehensif. Dari evaluasi yang penulis lakukan dapat disimpulkan beberapa hal. Pertama, keterlaksanaan program yang mencakup pemenuhan standar isi, standar proses, standar tenaga didik, standar sarana prasarana pembelajaran, standar penilaian, dukungan internal dan eksternal masih berada pada level yang rendah sehingga berimbas pada tingkat ketercapaian yang rendah pula. Kedua, pembelajaran yang ada selama ini masih belum efektif dan efisien. Ketiga, faktor-faktor penghambat program tahfidz dan BTQ adalah kurangnya kompetensi profesional guru, kurangnya sarana pembelajaran, kurangnya alokasi waktu, dan juga kurangnya perhatian dari orang tua siswa. Faktor pendukung program adalah kecerdasan siswa yang memadai. Keempat, langkah-langkah yang diambil sebagai bagian dari supervisi adalah dengan mengubah mindset siswa dan guru, memberikan bimbingan pada siswa dan guru secara rutin.
\end{abstract}

Kata kunci : Evaluasi, Supervisi, Pembelajaran al-Qur'an

\begin{abstract}
Many schools provide Qur'an education as an effort to improve the quality of students in the religious field. One of the schools that implements the Qur'an learning program is Islamic Bilingual Primary School of An-Nissa. That program is BTQ (reciting and writing al-Quran) and Tahfidz (memorizing al-Qur'an). As with other educational programs, Tahfidz and
\end{abstract}


BTQ programs must also be evaluated and supervised. This evaluation is intended to see the program's implementation and achievement, effectiveness and efficiency, to discover the program's supporting and inhibiting factors, and to find supervisory measures as a comprehensive development program. From the evaluation conducted by the author could conclude several things. First, the implementation of the program that covering the fulfillment of the content standards, process standards, the standard of the students, the standard of learning infrastructure facilities, the appraisal standards, internal and external support were still at a low level so that also impacted on the low level of achievement. Second, the existing learning has not been effective and efficient. Third, the inhibiting factors of tahfidz and BTQ programs are the lack of professional competence of teachers, lack of learning tools, lack of time allocation, and also lack of attention from students' parents. The supporting factor of the program is sufficient student intelligence. Fourth, the steps taken as part of the supervision were to change the mindset of students and teachers and provided guidance to them on a regular basis.

Keywords: Evaluasi, Supervisi, Pembelajaran al-Qur'an 


\section{PENDAHULUAN}

Mempelajari teori tajwid fardzu kifayah hukumnya, sedangkan membaca al-Qur'an sesuai dengan kaidah tajwid hukumnya fardzu 'ain. Artinya setiap muslim seharusnya mampu membaca al-Qur'an sesuai kaidah tajwid. Namun, dari hasil penelitianpenelitian yang ada mengindikasikan masih perlunya pembenahan dibidang ini.

Sebuah penelitian di Bandung menyebutkan bahwa dari 229.000 anak sekolah usia 6-12 tahun yang belajar mengaji al-Qur'an hanya 5.795, yang berarti sekitar 10\% (Himka, 2011). Penelitian di SMA Muhammadiyah 1 Sukoharjo yang dilakukan oleh Harun al-Rasyid menyimpulkan bahwa kebanyakan siswa belum bisa membaca alQur'an (Al-Rasyid, 2008: 4).

Banyak peraturan, baik peraturan pemerintah maupun peraturan daerah dibuat sebagai upaya untuk mengatasi masalah-masalah seperti di atas. Lembagalembaga pendidikan pun menawarkan program-program pembelajaran al-Qur'an sebagai wujud kepatuhan terhadap peraturan sekaligus memenuhi kebutuhan masyarakat.

Salah satu sekolah yang memberlakukan program pembelajaran al-Qur'an adalah Sekolah Dasar Islam Bilingual An-Nissa. Sebagai sekolah yang berlabel Islam, An-Nissa memiliki tanggungjawab kepada masyarakat untuk mempersembahkan prestasi lebih daripada sekolah lain yang tidak berlabel Islam dalam bidang keagamaan yang di antara elemen-elemennya adalah tahfidz (hafalan) dan Baca Tulis al-Qur'an (BTQ).

Sebagaimana progam-progam pendidikan yang lain, progam tahfidz dan BTQ juga harus dievaluasi dan disupervisi. Dalam pengamatan awal, penulis melihat adanya kegagalan dalam program ini yang diindikasikan dengan kualitas bacaan anak-anak yang tidak bagus meski umur program ini sudah empat setengah tahun. Ini tentu kurang sesuai dengan label "Islam" yang melekat di SDIB An-Nissa. Padahal jika dilihat dari prestasi An-Nissa yang mampu meraih lebih dari 100 piala kejuaraan tingkat lokal sampai nasional dalam kurun waktu empat setengah tahun ajaran (20072011) bisa menjadi indikasi bahwa siswa An-Nissa pintar-pintar.

Jika melihat usia SDIB An-Nissa (empat setengah tahun saat diteliti), jam pembelajaran, tingkat $I Q$, kemudian dibandingkan dengan kemampuan anak-anak maka penulis berasumsi ada masalah serius dengan manajemen progam tahfidz dan BTQ di sekolah ini sehingga membutuhkan evaluasi dan supervisi segera untuk kemajuan An-Nissa dalam bidang al-Qur'an. 


\section{KAJIAN TEORI}

\section{Evaluasi Program}

Berdasarkan kamus Oxford Advanced Learner's dictionary of Current English, evaluasi adalah upaya untuk menentukan nilai atau jumlah. Menurut Anne Anastasi evaluasi adalah a systematic process of determining the extent to which instructional objectives are achieved by pupils. Evaluasi merupakan kegiatan yang terencana dan sistematik untuk mengetahui keadaan suatu objek dengan menggunakan instrument dan hasilnya dibandingkan dengan tolak ukur untuk membuat kesimpulan (Arikunto, 2007:1).

Stufflebeam mendefinisikan evaluasi sebagai proses penggambaran, pencarian dan pemberian informasi yang bermanfaat bagi pengambil keputusan dalam menentukan alternative keputusan. Selanjutnya Direktorat Ditjen PLS Depdiknas mengartikan evaluasi program sebagai suatu proses pengumpulan dan penelaahan data secara berencana, sistematis dan dengan menggunakan metode dan alat tertentu untuk mengukur tingkat keberhasilan atau pencapaian tujuan program dengan menggunakan tolok ukur yang telah ditentukan.

Dari pengertian-pengertian yang dikemukakan oleh para ahli di atas, dapat disimpulkan bahwa evaluasi program merupakan penilaian dengan membandingkan antara pencapaian program dengan standar yang dirumuskan. Standar ini harus ada karena dengan standar bisa dilihat nilai dari suatu pencapaian. Standar evaluasi bisa berasal dari ketentuan dari departemen ataupun dari teori yang relevan. Hasil akhir evaluasi berupa data yang harus disusun dengan lengkap, cermat, terperinci, dan jelas. Hasil penilaian tersebut kemudian berfungsi sebagai acuan dalam pembuatan kebijakan-kebijakan selanjutnya.

Dari paparan di atas dapat dilihat bahwa evaluasi program memiliki beberapa unsur, yakni: objek yang dievaluasi, tujuan evaluasi, standar atau kondisi yang diharapkan, dan data hasil evaluasi yang valid dan dapat dipercaya.

Evaluasi program dapat dilaksanakan dengan berbagai model. Model-model tersebut antara lain: Goal Oriented Evaluation Model, Goal Free Evaluation Model, Formative-Summative Evaluation Model, Countenance Evaluation Model, CSE-UCLA Evaluation Model, CIPP Evaluation Model, Discrepancy Model, dan CIPPO (ContectInput-Process-Product-Outcomes) Evaluation Model. 
Setidaknya ada lima jenis evaluasi, yakni: evaluasi perencanaan dan pengembangan, evaluasi pemantauan, evaluasi dampak program, evaluasi efisiensi ekonomis, dan evaluasi program komprehensif. Adapun yang dimaksud subjek evaluasi adalah orang yang melakukan pekerjaan evaluasi. Siapa saja yang dapat disebut sebagai subjek di sini ditentukan oleh aturan pembagian tugas atau ketentuan yang berlaku (Arikunto, 1999: 9).

\section{Supervisi}

Supervisi merupakan hal yang sangat penting dalam kegiatan sekolah karena kegiatan sekolah merupakan hal penting dan mengikuti prinsip-prinsip manajemen dan administrasi yang mengarah kepada pencapaian tujuan pembentukan juga sebagai pribadi dan perseorangan (Arikunto, 2006: 370).

Piet A. Sehertian mengartikan supervisi sebagai usaha memberi layanan kepada guru baik secara individual maupun kelompok untuk memperbaiki pengajaran. P. Adams dan Frank G. Dickey mengatakan bahwa supervision is a planned program for the improvement of instruction (Arikunto, 2007: 275). Dalam Good Carter's Dictionary of Education supervisi adalah:

Segala sesuatu dari para pejabat sekolah yang diangkat yang diarahkan kepada penyediaan kepemimpinan bagi para guru dan tenaga kependidikan lain dalam perbaikan pengajaran, melihat stimulasi perkembangan dari para guru, seleksi dan revisi tujuan-tujuan pendidikan, bahan pengajaran, danmetode-metode mengajar, dan evaluasi pengajaran (Arikunto, 2007: 11).

Menurut Kimbal Willes, supervisi dimaksudkan untuk memperbaiki situasi belajar mengajar, menumbuhkan kreativitas guru, memberi dukungan dan mengikutkan guru dalam kegiatan sekolah sehingga menumbuhkan rasa memiliki (Sagala, 2006: 230).

Supervisi adalah kegiatan mengamati, mengidentifikasi mana hal-hal yang sudah benar, mana yang belum benar, dan mana pula yang tidak benar dengan maksud agar tepat dengan tujuan memberikan pembinaan (Arikunto, 2007: 5). Pembinaan dilakukan agar kualitas pembelajaran meningkat.

Secara mudah, konsep supervisi dapat diringkas dalam tiga proses, yakni: mencari data pelaksanaan untuk mengetahui kondisi nyata, membandingkan dengan kondisi harapan, dan mengadakan pembinaan untuk meningkatkan kondisi. 
Banyak pihak yang bisa dijadikan sebagai supervisor dalam pendidikan, antara lain: pengawas, kepala sekolah, wakil kepala sekolah, bidang kurikulum, wali kelas, petugas perpustakaan dan petugas bimbingan dan konseling. Jika dikaitkan dengan teori pembelajaran, maka gurulah yang paling tepat menjadi supervisor karena mereka yang paling dekat dengan murid dan menjadi ujung tombak dalam keberhasilan proses pembelajaran (Arikunto, 2007: 72).

Namun, perkembangan mutakhir yang dikemukakan oleh Sergiovanni menyebutkan bahwa supervisi bukan hanya dilakukan oleh pejabat yang sudah ditunjuk tapi oleh seluruh personel yang ada di sekolah. Pendapat ini didasarkan argumen bahwa tujuan supervisi adalah meningkatnya prestasi siswa, dan prestasi ini dipengaruhi oleh banyak personel dan banyak hal, yakni siswa itu sendiri, peralatan, lingkungan, dll. Menurut penulis, prestasi siswa memang dipengaruhi oleh banyak aspek, namun untuk supervisi, tidak bisa oleh sembarang orang, harus ada satu koordinator puncak, namun dalam kerjanya, koordinator ini bisa meminta informasi dan bantuan dari banyak pihak.

Langkah-langkah supervisi meliputi: perencanaan, persiapan, pelaksanaan, tindak lanjut berupa program pembinaan dan perbaikan berdasarkan hasil temun, dan yang terakhir adalah pelaporan. Adapun teknik-teknik yang bisa digunakan dalam supervisi antara lain: kunjungan kelas, pertemuan pribadi, rapat staff, kunjungan antar kelas, pertemuan KKG, kunjungan antar KKG, sistem magang, penataran, karya wisata, melalui media: buletin, koran, televisi atau radio.

\section{Keterkaitan Supervisi dengan Evaluasi}

Melihat konsep evaluasi dan supervisi yang berbeda-beda antar satu tokoh dengan tokoh lainnya terkadang menimbulkan kesan tumpang tindih. Menurut penulis, evaluasi dan supervisi memiliki hubungan yang erat. Tidak ada supervisi yang berjalan tanpa evaluasi. Namun, tidak demikian sebaliknya. Jika digambarkan dengan lingkaran, maka evaluasi adalah lingkaran kecil yang berada dalam lingkaran besar supervisi. Hubungan ini penulis coba gambarkan lewat gambar 1 di bawah ini. 


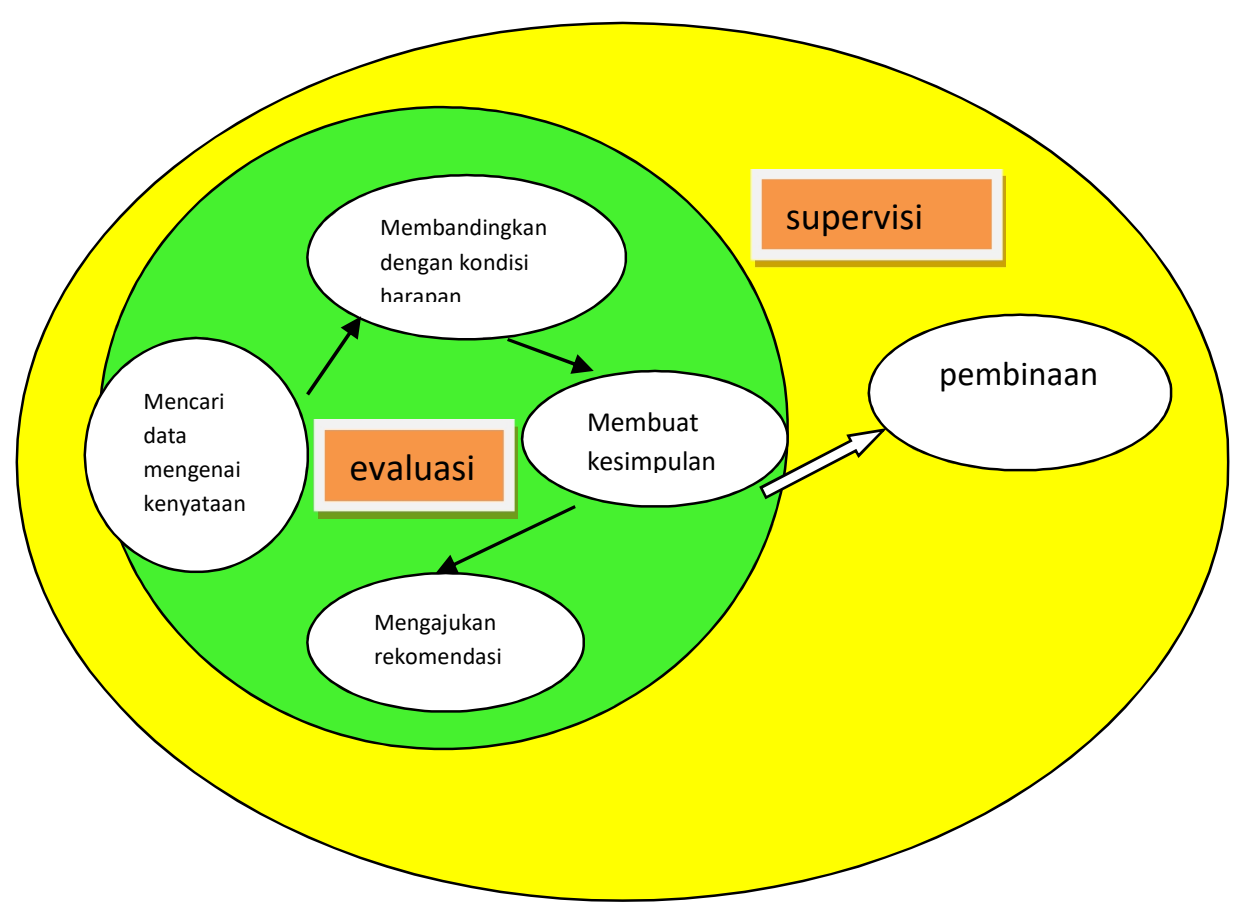

Gambar 1. Hubungan Evaluasi dan Supervisi

Gambar di atas dapat diterjemahkan sebagai berikut.

1. Evaluasi merupakan kegiatan bagian dari supervisi

2. Evaluasi adalah cara kerja supervisi

3. Evaluasi merupakan langkah awal supervisi yang menyediakan data untuk tahap lanjutan dalam supervisi.

Keseluruhan proses evaluasi berada dalam lingkaran hijau, sedangkan supervisi meliputi area hijau dan kuning.

\section{Landasan Hukum Program Tahfidz dan Baca Tulis Al-Qur'an}

Progam tahfidz dan Baca Tulis al-Qur'an (BTQ) ini merupakan bagian dari pendidikan agama (Islam). Aturan tentang pendidikan agama merupakan derivikasi dari Undang-undang Sistem Pendidikan Nasional. Fungsi pendidikan nasional yang termaktub dalam Undang-Undang R.I Nomor 20 tahun 2003 (tentang sistem pendidikan nasional) bab II pasal 3 adalah mengembangkan kemampuan dan membentuk watak serta peradaban bangsa yang bermartabat dalam rangka mencerdaskan kehidupan bangsa, mengembangkan potensi peserta didik agar menjadi manusia yang beriman, bertakwa kepada Tuhan Yang Maha Esa, berakhlak 
mulia, sehat, berilmu, cakap, kreatif, mandiri, dan menjadi warga Negara yang demokratis serta bertanggung jawab. Untuk mencapai tujuan ini, Undang-Undang pokok tentang sistem pendidikan nasional ini diderivikasikan dalam berbagai macam peraturan pendidikan, di antaranya dalam peraturan tentang standar pendidikan yang kemudian dilanjutkan dengan peraturan tentang pendidikan agama dan keagamaan.

Adapun peraturan-peratuaran terkait al-Qur'an yang muncul setelah Undangundang Sisdiknas No. 20 tahun 2003 antara lain adalah Permendiknas No. 22 tahan 2006 tentang standar isi yang menempatkan mata pelajaran agama sebagai kelompok pertama dalam kurikulum pendidikan dasar dan menengah. Pelajaran agama ini jika dikaitan dengan Islam maka yang menjadi landasan awal adalah al-Qur'an. Selanjutnya jika merujuk pada Peraturan Pemerintah N. 55 tahun 2007 pasal 24, maka tujuan pendidikan al-Quran adalah ntuk meningkatkan kemampuan peserta didik dalam membaca, menulis, memahami dan mengamalkan kandungan al-Qur'an. Masih dalam pasal yang sama disebutkan bahwa kurikulum pendidikan al-Qur'an adalah membaca, menulis dan menghafal ayat-ayat al-Qur'an, tajwid serta menghafal do'a-do'a utama (harian).

Usaha-usaha peningkatan kemampuan membaca dan menulis al-Qur'an telah dilakukan pemerintah sejak dulu, namun sampai saat ini masih banyak masyarakat yang belum mampu membaca al-Qur'an dengan baik. Contoh data yang bisa kita lihat adalah apa yang telah penulis paparkan dalam pendahuluan. Selain itu adalah apa yang penulis observasi dalam kantor pusat beberapa cabang perusahaan yang para karyawannya berkumpul menjadi satu dalam majlis pengembangan kemampuan membaca al-Qur'an. Ustadz Afif Muhyidin dari Lembaga Pengembangan Tilawatil Qur'an Jawa Tengah yang berlaku sebagai mentor dalam progam itu mengetes. Penulis menemukan bahwa dari keseluruhan peserta, yang bisa membaca dengan cukup baik tidak lebih dari sepuluh persen.

\section{Metode Pembelajaran Tahfidz dan Baca Tulis al-Qur'an}

Belajar al-Qur'an secara mandiri melalui buku belumlah cukup. Harus ada talaqqi, yakni murid bertemu langsung dengan guru yang memiliki sanad (kesinambungan guru sampai pada Nabi Muhammad SAW) untuk memperdengarkan bacaannya agar guru dapat mengoreksi secara langsung dan membimbingnya dengan meminta murid untuk memperhatikan gerak bibir dan lidahnya. Ada beberapa 
metode pembelajaran al-Qur'an yang berkembang di Indonesia, antara lain: metode baghdadiyah, iqro', qiro'ati, al-barqy, tilawati, yanbu'a, dan lainnya.

Metode yanbu'a menggunakan modul yang terdiri atas enam jilid utama ditambah satu jilid dasar, satu jilid tambahan tentang tajwid dan satu jilid yang berisi tentang bimbingan cara mengajar. Materinya terdiri atas pengenalan huruf dan harakat, makharij (tempat keluarya) huruf, tajwid, gharaib, penjelasan tentang tulisan rasm (bentuk) ustmany dan keumuman model penulisan di Indonesia, serta materi hafalan do'a-do'a harian dan penulisan model Arab pegon.

Pembelajaran metode ini secara umum mirip dengan Qiro'ati, yakni klasikal dan privat. Klasikal dilakukan dengan cara guru memberikan contoh dan ditirukan siswa secara berulang-ulang. Privat dilakukan dengan cara siswa membaca di depan guru dan dikoreksi oleh guru jika ada yang salah. Adapun pengenalan gharaib (bacaanbacaan yang tidak lazim, memiliki aturan pembacaan yang khusus) dilakukan dengan membacanya berulang-ulang sampai hafal. Yanbu'a memiliki rincian-rincian panduan mengajar yang sangat banyak yang di antara berkaitan dengan materi-materi ilmu tajwid, qira'ah dan rasmi seperti yang telah dibahas di atas.

\section{PEMBAHASAN}

\section{Gambaran Umum SD Islam Bilingual An-Nissa}

Sekolah Dasar Islam Bilingual An-Nisa terletak Jl. Piere Tendean No. 28, Sekayu, Semarang Tengah. Namun mulai tahun 2014 pindah ke jl. Abimanyu Raya. Sekolah ini termasuk lembaga pendidikan swasta. SD Islam Bilingual An-Nissa didirikan pada tanggal 1 April 2007, yang dibangun untuk menjawab permasalahan masyarakat. Beberapa permasalahan yang menjadi latar belakang berdirinya SDIB An-Nissa adalah belum adanya pola pendidikan dasar yang terintegrasi dalam praktek pembelajarannya, masih terlalu banyaknya jumlah peserta didik di setiap kelas, kegiatan masih berpusat di kelas/sekolah. Masih banyaknya Sekolah Dasar yang mengandalkan Pendidikan yang belum memiliki Standar kompetensi. Sarana dan prasarana yang sangat minim.

Visi sekolah adalah "Mencetak generasi muda yang mampu berbahasa internasional dan menguasai IPTEK dan IMTAQ". Sedangkan misinya adalah 1). Mengupayakan peningkatan kualitas Sumber Daya Manusia (SDM) melalui bidang pendidikan. 2). Meningkatkan pemberdayaan dan optimalisasi potensi umat guna 
56 | Jurnal Tarbawi Vol. 15. No. I. Januari - Juni 2018

mendukung keberadaan Lembaga Pendidikan. 3). Mewujudkan peningkatan kualitas sumber daya manusia dengan biaya murah, modern dan bermartabat.

\section{Program Unggulan}

Dalam rangka mewujudkan visi sekolah, salah satunya adalah pengembangan siswa melalui program unggulan sekolah yang dilaksanakan selaras dengan kurikulum, antara lain yaitu :

a. Pengelompokkan kelas dibagi rata antara siswa yang berkemampuan lebih dan siswa kurang sehingga terbentuk semua kelas menjadi unggulan.

b. Pelaksanaan pembelajaran dengan Quantum Learning, Active Learning, Multi Metode, dan Multi Media

c. Pendidikan Agama Islam (Baca Tulis al-Qur'an dengan menggunakan metode yanbu'a).

d. Pengembangan wawasan kebangsaan dalam rangka memupuk serta menumbuhkembangkan rasa cinta tanah air dan budaya Indonesia yang beraneka ragam.

e. Pengembangan kemampuan dwi bahasa (Indonesia \& Inggris), tanpa melupakan jatidiri bangsa Indonesia dan kultur Jawa.

f. Pengembangan ketrampilan diri siswa berkaitan dengan mata pelajaran melalui ketrampilan komputer, jarimatika, pendidikan agama Islam (Sholat berjamaah dan BTQ), seni musik. ${ }^{1}$

\section{Progam Tahfidz dan Baca Tulis al-Qur'an (BTQ) SD Islam Bilingual An-Nissa}

Program Tahfidz dan Baca Tulis al-Qur'an di SD Islam Bilingual An-Nissa memiliki beberapa tujuan, diantaranya; 1). membentuk generasi yang mencintai alQur'an dan menjadikannya sebagai kegiatan sehari-hari. 2). Melatih siswa untuk membaca dengan al-Qur'an dengan fasih dan tartil. 3). Melatih siswa untuk mampu menulis kalimat-kalimat dalam al-Qur'an dengan baik. 4). Melatih siswa untuk menghafalkan juz ‘amma.

${ }^{1}$ Data tentang gambaran umum SDIB diambil dari situs resmi SDIB An-Nissa Semarang, brosur SDIB serta wawancara tidak resmi dengan guru-guru. 


\section{Materi dan Metode Pembelajaran Tahfidz dan Baca Tulis al-Qur'an (BTQ)}

Metode yang digunakan di SDIB An-Nisa adalah Yanbu'a sehingga otomatis materinya adalah apa yang ada dalam modul Yanbu'a. Hal- hal penting mengenai materi dan metode yang digunakan dapat dirumuskan dalam beberapa point sebagai berikut.

a. Materi-materi di ajarkan secara berjenjang sesuai dengan urutan modul dari juz (jilid) 1 sampai 7 .

b. Menekankan pada bagaimana membaca dengan fasih, tartil, sesuai dengan kaidah ilmu tajwid serta lancar.

c. Menghafal juz 'amma dengan rincian target:

1) Kelas satu surat al-fatihah (QS: 1), an-nas (QS: 114), al-falaq (QS: 113), al-ikhlas (QS: 112), al-lahab (QS: 111), an-nashr (QS: 110), al-kafirun (QS: 109), al-kautsar (QS: 108) dan al-ma'un (QS: 107).

2) Kelas dua surat al-quraisy (QS: 106), al-fiil (QS: 105), al-humazah (QS: 104), al-'ashr (QS: 103), al-takatsur (QS: 102), al-qari'ah (QS: 101), al'adiyat (QS: 100)

3) Kelas tiga surat al-zalzalah (QS: 99), al-bayyinah (QS: 98), al-qadr (QS: 97), al-alaq (QS: 96), at-tin (QS: 95), al-insyirah (QS: 94).

4) Kelas empat surat adh-dhuha (QS: 93), al-lail (QS: 92), asy-syamsu (QS: 91), al-balad (QS: 90), al-fajr (QS: 89), al-ghasyiyah (QS: 88)

5) Kelas lima surat al-a'la (QS: 87), ath-thariq (QS: 86), al-buruj (QS: 85), alinsyiqaq (QS: 85), al-muthaffifin (QS: 83).

\section{Evaluasi dan Supervisi Program Tahfidz dan Baca Tulis al-Qur'an Model (Tipe) Evaluasi dan Supervisi yang Digunakan}

Evaluasi yang penulis gunakan adalah jenis evaluasi program komprehensif yang menggunakan CIPPO (Contect-Input-Process-Product-Outcomes) evaluation model. Dengan demikian yang menjadi sasaran tidak hanya satu hal tetapi banyak hal yang mempengaruhi keberlangsungan program.

Adapun tipe supervisi yang digunakan adalah training and guidance dipadukan dengan tipe demokratis. Tipe training and guidance berarti supervisor memberikan latihan dan bimbingan. Tipe demokratis memberikan ruang yang lebih luas kepada pihak yang disupervisi untuk ikut berbicara menyampaikan aspirasi. Tipe demokratis 
mengisyaratkan bahwa supervisi ini terselip dalam fungsi-fungsi dinamis manajemen, yaitu koordinasi, pengarahan dan evaluasi (Arikunto, 2007: 14-17).

Supervisi dimulai dengan proses menemukan fakta-fakta (melalui proses evaluasi) terkait dengan program tahfidz dan Baca Tulis al-Qur'an, membandingkan dengan standar yang telah ada, yakni dari peraturan-peraturan pemeritah yang relevan, ilmu tajwid, qira'ah, ilmu rasmi dan juga ilmu tentang metodologi pembelajaran al-Qur'an, lalu dilanjutkan dengan membentuk program-program pembinaan sebagai wujud supervisi yang komprehensif.

\section{Komponen-komponen yang dievaluasi dan supervisi}

Pelaksanaan supervisi progam tahfidz dan Baca Tulis al-Qur'an (BTQ) di SDIB an-Nissa dilaksakan dengan menilai beberapa hal, antara lain: buku bahan ajar yang digunakan, materi-materi yang diajarkan, guru yang bertugas mengajar, wali siswa, peningkatan pengetahuan siswa dalam bidang al-Qur'an, prestasi siswa dalam menghapal, membaca dan menulis al-Qur'an, dan sarana yang menunjang progam.

Pihak-pihak yang terlibat dalam proses evaluasi dan supervisi program tahfidz dan BTQ ini adalah kepala sekolah, koordinator program, para guru, para siswa dan wali siswa.

\section{Hasil evaluasi dan supervisi}

\section{a. Keterlaksanaan dan ketercapaian progam tahfidz dan BTQ di SDIB An-Nissa}

Keterlaksanaan program mencakup lima hal yaitu: pemenuhan standar isi dan SKL (standar kelulusan), standar proses, standar tenaga pendidik, standar sarana dan prasarana dan standar penilaian. Standar isi program ini sudah jelas sebagaimana dijelaskan di atas, yakni berasal dari Yanbu'a dan juga hafalan surat-surat pendek juz 30. Adapun standar kelulusannya pun juga sudah diatur oleh Yanbu'a. Kelulusan hanya akan dicapai apabila anak sudah mampu membaca dengan lancar dan benar tanpa "mikir-mikir" lagi. Namun, yang terjadi di lapangan, standar-standar tersebut belum dapat dipenuhi. Hal ini bisa dilihat dari hasil observasi, dari 312 anak yang penulis cek bacaannya, tidak lebih dari 10\% yang mampu membaca (dengan melihat tulisan) dengan cukup baik. Demikian juga dengan bacaan tahfidz (hafalan tanpa melihat tulisan), banyak sekali kesalahan.

Dalam hal menulis, pencapaian siswa cukup bagus meski mereka menggunakan metode "melukis" untuk menulis, sehingga banyak yang menulis dari kiri atau menggunakan guratan-guratan yang rumit. Namun, menurut penulis itu masih 
mudah untuk diperbaiki. Masalah yang lebih serius adalah dalam hal bacaan, sehingga di sini masalah ini dibahas dalam porsi yang lebih besar dibanding masalah tulisan.

Secara kuantitas, pencapaian bidang tahfidz dan bacaan al-Qur'an cukup baik karena mampu mencapai target tiap semesternya. Namun, secara kualitas, hasil evaluasi masih ada beberapa kesalahan bacaan siswa. Kesalahan yang umum

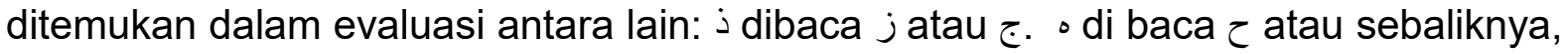
ص dibaca ش $ش$ dll. Ini dikarenakan guru yang mengajarkan berpatok pada ejaan transliterasi dan tidak memahami huruf-huruf hija'iyyah dan masing-masing makhraj atau tempat keluarnya huruf secara benar. Kesalahan-kesalahan makhraj ini secara umum masuk ke dalam kategori lahn jally. Adapun kesalahan halus dalam pelafalan yang biasanya berkaitan dengan sifatul huruf selama tidak sampai merusaak makna masuk ke dalam kategori lahn khafy. Kesalahan lain yang sangat sering terjadi adalah dari permasalahan mad, idhar, idgham, ikhfa', pelafalan lafadz الله yang disambungkan dengan harakat kasrah, dzummah, dan fathah.

Melihat daftar kesalahan yang ada dapat diartikan bahwa pencapaian dalam segi kualitas sangat rendah. Jenis-jenis kesalahan dalam membaca jilid maupun melafalkan hapalan juz 'amma hampir sama. Rata-rata siswa harus mengulang bacaan di atas lima puluh kali untuk bisa mencapai standar yang penulis gunakan dalam hal bacaan al-Qur'an sesuai dengan panduan dari Yanbu'a. Hal yang sama juga terjadi pada guru-guru ketika belajar. Hal seperti ini disebabkan karena lisan mereka sudah terlanjur biasa melafalkan dengan cara yang keliru selama bertahuntahun. Ketercapaian hasil pembelajaran tersebut tentu tidak terlepas dari standarstandar proses, pendidik, sarana dan penilaian yang digunakan.

Dari segi standar proses, standar tenaga pendidik, sarana dan standar penilaian masih jauh dari standar yang telah ditetapkan oleh Yanbu'a. Alokasi waktu yang disediakan sangat sedikit jika diukur dengan jumlah siswa berdasarkan standar pembelajaran metode yanbu'a. Standar waktu pembelajaran yanbu'a adalah 60-75 menit dengan jumlah siswa 15 untuk jilid (juz) 1 dan 2, 20 anak untuk jilid 3 ke atas. Di An-Nissa pembelajaran yang berlangsung untuk BTQ perminggunya hanya 35 menit per kelas. Untuk jam tahfidz sudah cukup waktunya, yaitu setengah jam setiap harinya dengan metode klasikal.

Berapapun alokasi waktu yang disediakan, sebenarnya kuncinya ada pada standar pendidik yang masih belum bagus. Karena ini pembelajaran al-Qur'an, maka 
pengajar dituntut menguasai cara membaca al-qur'an yang benar, tata cara pengajaran dan tata cara menilai yang baik. Namun, yang terjadi tidak demikian, sehingga selama ini (sebelum penulis masuk sebagai pengajar) SDIB An-Nissa dalam bidang al-Qur'an lebih terpaku pada kuantitas karena standar penilaian pun rendah. Anak sudah sampai pada jilid tinggi namun ternyata belum lancar membaca teks jilid bawahnya. Standar yanbu'a, anak tidak boleh naik jilid sampai benar-benar menguasai jilid bawahnya. Menaikkan level sebelum level bawah dikuasai akan memperumit kerja otak anak. Prinsipnya, belajar harus dimulai dari hal-hal yang mudah dan sederhana dulu lalu naik pada level yang lebih rumit dan kompleks.

Dari segi sarana pembelajaran juga belum terpenuhi dengan baik karena sekolah tidak memiliki alat peraga dan hampir semua siswa masih menggunakan modul pinjaman dari sekolah. Mereka tidak memiliki secara pribadi sehingga mereka tidak leluasa memberikan tanda-tanda tertentu pada tiap halaman apabila melakukan kesalahan dalam membaca. Selain itu mereka juga tidak leluasa membawa pulang modul itu dengan alasan takut hilang karena itu milik sekolahan.

\section{Efektivitas dan efisiensi program tahfidz dan BTQ di SDIB An-Nissa}

Melihat uraian dalam poin pertama mengenai keterlakssaaan dan ketercapaian program dapat dilihat bahwa tingkat efektivitas dan efisiensi proram masih rendah. Hal ini (antara lain) karena masih rendahnya kompetensi profesional dari guru yang mengajar, sehingga meski tiap pagi ada waktu khusus untuk tahfidz dan baca tulis al-Qur'an, hasil pembelajarannya tidak memenuhi standar mutu dari yanbu'a. Sebab lain adalah masih belum terpenuhinya sarana sesuai dengan standar pembelajaran tahfidz dan Baca Tulis al-Qur'an.

Tidak adanya alat peraga membuat pembelajaran tidak efektif, apalagi untuk kelas awal. Alat peraga menjadi sangat penting jika dihubungkan dengan jumlah siswa dan alokasi waktu yang disediakan kurang imbang. Untuk anak-anak kecil, yang dibutuhkan adalah waktu yang cukup untuk mendengar secara berulang-ulang pelafalan yang benar lalu menirukannya secara berulang-uang pula. Ketelitian seorang guru sangat diperlukan. Jika ada alat peraga, maka fokus anak akan lebih mudah dikendalikan untuk melihat alat peraga, mendengarkan guru, lalu menirukannya secara berulang-ulang. 
Faktor penghambat dan pendukung keterlaksanaan program tahfidz dan BTQ di SDIB An-Nissa

\section{1) Faktor siswa}

Motivasi mayoritas siswa untuk belajar cukup baik dengan indikator bahwa mereka sering berebut untuk maju dahulu di hadapan guru untuk menyetorkan atau menyimakkan bacaan mereka di depan guru pengampu. Ini sebenarnya mampu mendukung program dengan baik jika siswa berada di bawah bimbingan guru yang kompeten, apalagi kecerdasan anak-anak terhitung cukup baik jika dilihat dari prestasi belajar mereka dalam mata pelajaran lain. Bukti kecerdasan mereka juga bisa dilihat dari kuantitas hafalan surat-surat pendek mereka. Apa yang diajarkan guru terserap dengan baik. Soal yang diajarkan benar atau salah adalah hal lain dari kecerdasan mereka. Masalah yang muncul setelah program pembinaan dilakukan adalah beberapa siswa merasa "sudah bisa" sehingga mereka enggan untuk memperbaiki bacaan yang sebenarnya masih kurang baik.

\section{2) Faktor guru}

Dari hasil evaluasi di atas dapat dilihat tingkat kompetensi guru dalam bidang al-Qur'an masih sangat rendah, sedangkan mereka tiap hari harus mengajarkan Baca Tulis al-Qur'an dan tahfidz pada siswa. Dengan demkian tidak ada kesinkronan antar bidang yang diajarkan dengan kompetensi guru. Hal ini akan menjadi lebih parah jika kesadaran guru akan kemampuannya sendiri masih rendah. Atau ada yang tahu tapi mereka merasa tidak cukup waktu untuk memperbaikinya.

\section{3) Faktor wali murid}

Wali murid terhitung kurang peduli dalam bidang ini dengan indikator sedikitnya siswa yang mengaji di rumah, baik di TPQ, dengan guru les atau di bawah bimbingan orang tua sendiri. Ini menjadi faktor penghambat suksesnya program karena sekolah hanya menyediakan waktu satu jam pelajaran (35 menit) per minggu untuk BTQ dan 30 menit per hari untuk tahfid. (Sebenarnya jam tahfidz ini cukup banyak, namun masalahnya jam itu diisi oleh guru-guru yang belum bagus bacaan al-Qur'annya).

\section{4) Faktor sistem di sekolah}

Sekolah terhitung lambat dalam menyikapi permasalahan dalam program ini. Sebagai contoh adalah belum terwujudnya program pengadaan sarana pembelajaran yang memadai. 
62 | Jurnal Tarbawi Vol. 15. No. I. Januari - Juni 2018

\section{Langkah-langkah yang diambil sebagai program pembinaan yang komprehensif}

Mengadaptasi teori tentang proses peningkatan kemampuan profesional guru (Bafadal, 2006: 42-46), proses peningkatan kemampuan agar efektif dan efisien menggunakan langkah-langkah:

1. mengidentifikasi kekurangan, kelemahan, kesulitan, atau masalah-masalah yang dialami

2. menetapkan progam peningkatan kemampuan

3. merumuskan tujuan progam peningkatan kemampuan yang diharapkan dapat dicapai pada akhir progam.

4. menetapkan serta merancang materi dan media yang akan digunakan dalam peningkatan

5. menetapkan serta merancang metode dan media yang akan digunakan dalam peningkatan

6. menetapkan bentuk dan mengembangkan instrumen penilaian yang akan digunakan dalam mengukur keberhasilan progam peningkatan

7. menyusun dan mengalokasikan anggaran progam

8. melaksanakan progam- progam dengan materi, metode, dan metode yang telah ditetapkan dan dirancang

9. mengukur keberhasilan progam peningkatan

10. menetapkan progam tindak lanjut peningkatan kemampuan

Dengan demikian, setelah masalah-masalah dalam program telah teridentifikasi sebagaimana sudah dipaparkan di atas, maka program-program lanjutan disusun untuk membina pihak-pihak terkait agar mutu program bisa segera diperbaiki. Program-program lanjutan tersebut adalah sebagai berikut:

a. Progam baru masalah sarana pembelajaran. Selama ini siswa tidak memiliki sendiri buku pegangan. Mereka hanya dipinjami, dan jika sudah pindah level, maka modul (juz/jilid) yang sudah diselesaikan dikembalikan. Ini menurut penulis tidak efektif. Dalam juz-juz ada materi pembelajaran menulis berupa tulisan yang tipis, lalu siswa diminta untuk menebali. Ini melatih anak untuk melenturkan jari-jari sesuai dengan bentuk tulisan yang bagus, setelah menebali tulisan cetak, anak diminta untuk menulis sendiri di buku tulis beberapa kali. Namun, karena selama ini modulnya dipinjami sekolahan, maka otomatis hampir keseluruhan siswa tidak melakukan hal itu. Alasannya tidak boleh menyoret-nyoret juz pinjaman, karena kelak akan dipakai oleh adik kelas. 
Menurut analisis penulis, berdasarkan pengalaman di dunia pesantren yang mampu mencetak para penghafal Qur'an yang handal, semua santri memiliki modul sendiri yang dipakai saat memperdengarkan cara mengajinya. Guru akan memberi tanda pada bagian-bagian yang salah sehingga murid dapat mempelajari kembali dengan memberi titik tekan yang lebih pada bagian yang salah. Kebanyakan anak memiliki titik-titik rawan salah sendiri-sendiri.

b. Pembelajaran rutin untuk para guru seminggu sekali. Materi pembelajaran adalah pelatihan membaca al-Qur'an dari dasar, yakni dari bagaimana melafalkan huruf-huruf hija'iyyah sesuai dengan aturan makhraj dan sifat huruf. Selanjutnya adalah materi tentang mad dan qashar, hukum tanwin, dan materimateri lain dalam Imu tajwid yang sudah dipaparkan dalam landasan teori. Hal ini dilakukan karena guru-guru kelas memiliki tugas mendampingi anak-anak dalam hafalan surat-surat pendek setiap pagi di kelas. Guru juga dilatih untuk meningkatan standar penilaian dan kelulusan dalam pembelajaran.

c. Pengecekan kemampuan guru dalam membaca al-Qur'an yang dilakukan rutin mingguan. Pengecekan ini dilakukan untuk melihat peningkatan kemampuan guru setelah mereka mengiuti program pembelajaran.

d. Pengecekan kemampuan siswa dalam bidang tahfidz. Pengecekan ini penulis lakukan kurang lebih sebulan sekali untuk melihat perubahan bacaan siswa. Ini sekaligus untuk melihat apakah guru telah mengaplikasikan apa yang mereka peroleh dalam pembelajarn mingguan untuk memperbaiki bacaan siswa-siswa yang ada dalam perwalian mereka. Untuk menilai hal ini penulis melihat model kesalahan siswa, apakah kesalahannya massal atau bersifat individual. Jika massal, artinya guru belum menangkap materi pembelajaran dengan baik.

e. Pembelajaran BTQ untuk siswa secara rutin yang penulis handle secara langsung. Program ini bertujuan untuk memperbaiki bacaan, memperdalam pemahaman terhadap konsep-konsep secara runtut, tidak loncat-loncat dan tidak terburu-buru.

\section{KESIMPULAN}

Dari evaluasi yang penulis lakukan dapat disimpulkan beberapa hal sebagai berikut.

a. Keterlaksanaan program yang mencakup pemenuhan standar isi, standar proses, standar tenaga didik, standar sarana prasarana pembelajaran, standar 
penilaian, dukungan internal dan eksternal masih berada pada level yang rendah sehingga berimbas pada tingkat ketercapaian yang rendah pula.

b. Pembelajaran yang ada selama ini masih belum efektif dan efisien

c. Faktor-faktor penghambat program tahfidz dan BTQ adalah kurangnya kompetensi profesional guru, kurangnya sarana pembelajaran, kurangnya alokasi waktu, dan juga kurangnya perhatian dari orang tua siswa. Faktor pendukung program adalah kecerdasan siswa yang memadai.

Langkah-langkah yang diambil sebagai bagian dari supervisi adalah dengan mengubah mindset siswa dan guru, memberikan bimbingan pada siswa dan guru secara rutin.

\section{DAFTAR PUSTAKA}

Al-Rasyid, Harun, Problematika Pembelajaran Baca Tulis al-Qur'an (BTQ)dan Solusinya (Studi Kasus di Kelas XII SMA Muhammadiyah 1 Sukoharjo Tahun Pelajaran) (skripsi) Fakultas Agama Islam Universitas Muhammadiyah Surakarta, 2008

Aly, Hery Noer dan Munzier S, Watak Pendidikan Islam, Jakarta: Friska Agung Insani, 2000

Arikunto, Suharsimi Dasar-dasar Evaluasi Pendidikan (Edisi Revisi), Jakarta: Bumi Aksara, 1999

, Dasar-dasar Supervisi, Jakarta: PT. Rineka Cipta, 2006

- Evaluasi Program Pendidikan; Pedoman Teoritis Praktis Bagi Praktisi Pendidikan, Jakarta:Bumi Aksara, 2007

Badwilan, Ahmad Salim, Seni Menghafal Al-Qur'an; Resep Manjur Meghafal al-Qur'an yang Telah Terbukti Keampuhannya (terj), Solo: Wacana IImiah Press, 2008 Bafadal, Ibrahim, Peningkatan Profesionalisme Guru Sekolah Dasar; dalam Kerangka Manajemen Peningkatan Mutu Berbasis Sekolah, Jakarta: Bumi Aksara, cetakan ke-tiga, 2006

Daradjat, Zakiah, IImu Pendidikan Islam, Jakarta: Bumi Aksara, 2000

Hamid, Ahmad Mahfudh, Pengantar Ilmu Tajwid dan Qiro'ah (Jepara: Pondok Pesantren Rodlotul Qur'an, 2003

Herabudin, Administrasi dan Supervisi Pendidikan, Bandung: CV. Pustaka Setia, 2009 Munir, Ahmad, Tafsir Tarbawi; Mengungkap Pesan al-Qur'an Tentang Pendidikan, Yogyakarta: Teras, 2008 
Mustamir, Sembuh \& Sehat dengan Mukjizat al-Qur'an, (Yogyakarta: Lingkaran, 2007 Nata, Abuddin, Perspektif Islam Tentang Pola Hubungan Guru-Murid (Studi Pemikiran Tasawuf Al-Ghozali), Jakarta: PT. Raja Grafindo Persada,2001

Peraturan Pemerintah N. 55 tahun 2007 Tentang Pendidikan Agama dan Keagamaan Permendiknas No. 22 tahan 2006 Tentang Standar Isi

Rohani, Ahmad dan Abu Ahmadi, Pedoman Penyelenggaraan Administrasi Pendidikan Sekolah, Jakarta: Bumi Aksara, 1991

Roqib, Moh, Prophetic Education; Kontekstualisasi Filsafat dan Budaya Profetik dalam Pendidikan, Purwokerto: STAIN Press, 2011

Rubiyanto, Nanik dan Dany Haryanto, Strategi Pembelajaran Holistik di Sekolah, Jakarta: Prestasi Pustakaraya

Sagala, Syaiful, Administrasi Pendidikan Kontemporer, Bandung: Alfabeta, 2006

Sujana, Nana, dkk., Buku Pengawas Sekolah, Pusat Pengembangan Tenaga Kependidikan, Badan PSDM dan PMP Kementrian Pendidikan Nasional, 2011

Suyanto, Dialog Interaktif Tentang Pendidikan (dari Konseptual Menggelitik Sampai yang Ringan dan Ringan Sekali), Yogyakarta: Multi Pressindo, 2008

Syukur, M. Amin dan Fathimah Usman, Terapi Hati dalam Seni Menata Hati, Semarang: Pustaka Nun, 2009

Thoha, M. Chabib, Teknik Evaluasi Pendidikan, Jakarta: PT. Raja Grafindo Persada, 1996

Thoriqoh Baca Tulis dan Menghafal al-Qur'an Yanbu'a juz 1-7, Kudus: Pondok Tahfidh Yanbu'ul Qur'an

Tilaar, H.A.R., Standarisasi Pendidikan Nasional; Suatu Tinjauan Kritis, Jakarta: PT. Rineka Cipta, 2006

Undang-undang Sistem Pendidikan Nasional No. 20 tahun 2003 
66 | Jurnal Tarbawi Vol. 15. No. I. Januari - Juni 2018

Evaluasi dan Supervisi Program Pembelajaran Al-Qur'an di Sekolah Dasar Islam Bilingual An-Nissa Semarang 